\title{
IDENTIFIKASI MUTU BIJI KOPI ARABIKA BERDASARKAN CACAT DENGAN TEKNIK CONVOLUTIONAL NEURAL NETWORK
}

\author{
Mahmuda Saputra ${ }^{1}$, Kusrini ${ }^{2}$, Mei P Kurniawan ${ }^{3}$ \\ Magister Teknik Informatika, Universitas AMIKOM Yogyakarta ${ }^{123}$ \\ Email : mahmudasaputra@gmail.com ${ }^{1}$, kusrini@amikom.ac.id ${ }^{2}$, \\ meikurniawan@amikom.ac.id ${ }^{3}$
}

\begin{abstract}
ABSTRAK
Dalam proses pengemasan saat ini, penyortiran ini dilakukan secara manual. Dalam penelitian ini, convolution neural network diterapkan untuk secara otomatis untuk mengetahui informasi kecacatan biji kopi arabika. Input yang digunakan dalam penelitian ini adalah gambar biji kopi arabika dengan proses penguraian yang telah dikeringkan. Skenario yang terlibat dalam penelitian ini adalah pengumpulan data, preprocessing, klasifikasi dan pengujian. Preprocessing dilakukan dengan memotong beberapa cakupan objek biji kopi yang hanya berisi gambar biji kopi. Klasifikasi dilakukan oleh CNN, untuk mendapatkan akurasi model yang terbaik, parameter yang ada harus diuji dan dievaluasi. Pengujian dilakukan untuk dua jenis model, model 2 kelas dan model 4 kelas. Hasil percobaan menunjukkan bahwa akurasi terbaik yang diperoleh untuk model 2-kelas adalah 82,46\% dengan menggunakan tingkat pembelajaran 0,0001, konvolusi lapisan tunggal dengan lima belas filter dan 100 neuron pada lapisan tersembunyi. Ukuran filter adalah 3x3x3. Sedangkan model 4-kelas memperoleh akurasi terbaik 70,73\% dengan dua lapisan konvolusional. Jumlah filter di setiap lapisan adalah 6 filter dengan ukuran $3 \times 5 \times 5$ di lapisan pertama dan 18 filter dengan ukuran $6 \times 3 \times 3$ di lapisan kedua
\end{abstract}

Kata Kunci: Kopi, Arabika, CNN, Klasifikasi

\begin{abstract}
In the current packaging process, this sorting is done manually. In this study, convolution neural network (CNN) is applied to automatically find out information on Arabica coffee bean defects. The input used in this study is a picture of Arabica coffee beans with the process of decomposition that has been dried. The scenarios involved in this research are data collection, preprocessing, classification and testing. Preprocessing is done by cutting some coffee beans that only contain coffee beans. Classification is done by CNN, to get the best model accuracy, parameters that must be approved and evaluated. The test is conducted for two types of models, model 2 class and model 4 class. The experimental results show that the best test obtained for the 2-class model is $82.46 \%$ using a learning rate of 0.0001 , a single layer convolution with fifteen filters and 100 neurons in the hidden layer. The filter size is $3 \times 3 \times 3$. Whereas the 4-class model receives the best accuracy of $70.73 \%$ with two convolutional layers. The number of filters in each layer is 6 filters with size $3 \times 5 \times 5$ in the first layer and 18 filters with size $6 \times 3 \times 3$ in the second layer.
\end{abstract}

Keywords: Coffee, Arabica, CNN, Classification 


\section{PENDAHULUAN}

Kopi merupakan sebuah komoditas tropis utama yang telah diperdagangkan di seluruh dunia dengan kontribusi setengah dari total ekspor komoditas tropis. Popularitas dan daya tarik dunia terhadap kopi, utamanya dikarenakan rasanya yang unik serta didukung oleh faktor dari sejarah, tradisi, sosial dan kepentingan ekonomi. Dalam perkembangannya, keberhasilan suatu agribisnis kopi sangat membutuhkan dukungan semua pihak yang terkait serta proses produksi kopi hingga pengolahan dan pemasaran komoditas kopi. Saat ini di Indonesia merupakan negara pengekspor kopi nomor empat terbesar dan produsen kopi ketiga setalah negara Brazil dan Vietnam. Proses distribusi kopi dimulai dari petani, kemudian petani menjual ke pengepul, pengepul menjual kopi ke eksportir dan eksportir ke dalam negeri maupun luar negeri. Sebelum kopi diekspor maupun dipasarkan, tentunya eksportir akan memberikan sampel kopi ke petugas (Balai Pengujian dan Sertifikasi Mutu Barang) untuk diuji, dan petugas akan menguji sampel kopi yang diberikan eksportir berdasarkan Standart Nasional Indonesia (SNI) untuk mendapatkan sertifikat.

Ide penelitian ini dibangun berdasarkan pengamatan dari permasalahan sebelumnya, yaitu adanya kecacatan pada biji buah kopi sebelum di ekspor. Biji kopi tersebut dipilih dengan jenis kopi arabika. Kopi tersebut terlebih dahulu di sortir untuk mendapatkan biji kopi kering. Tahapan selanjutnya peneliti akan mengambil beberapa sampel biji kopi yang telah capture sebagai data citra awal untuk dataset dalam proses training dengan penerapan metode convolutional neural network.

Adapun ruang lingkup yang penelitian dibatasi pada (1) Jenis kopi yang digunakan berupa kopi arabika yang proses biji kopi kering, (2) Citra yang digunakan adalah citra berekstensi .jpeg,(3) Data input dan data uji merupakan citra kopi yang bersumber dari internet,(4) Penerapan klasifikasi citra berdasarkan arsitektur convolutional neural network,serta (5) Data diolah menggunakan bantuan library keras dan menggunakan bahasa pemrograman python. Tujuan penelitian tersebut untuk mengetahui hasil klasifikasi citra pada pemilihan mutu biji kopi dari jenis kopi arabika dengan library keras dan python. Sehingga terdapat akurasi citra dari setiap label kecacatan biji kopi.

Pada penelitian (Effendi, Fitriyah, and Effendi 2017)Adanya pengidentifikasian terhadap jenis dan mutu teh dari 3 jenis teh yaitu teh hitam, teh hijau, dan teh putih perlu dilakukan. Tujuan penelitian ini untuk merancang sebuah aplikasi sistem pengolahan citra digital untuk mengidentifikasi jenis dan mutu teh serta menentukan hasil pengenalan terbaik berdasarkan akurasi yang diperoleh. Penelitian ini menerapkan metode pengolahan citra digital dengan teknik LVQ yang menggunakan enam parameter warna yaitu R, G, B, H, S, dan I sebagai neuron input dan 13 mutu dari 3 jenis teh sebagai neuron output. Penelitian menggunakan 403 citra dengan perbandingan training dan testing sebesar 80:20. Akurasi training diperoleh sebesar $62,7 \%$. Prediksi menggunakan 26 sampel 
citra teh berbeda menunjukkan tingkat akurasi sebesar $42,31 \%$.

Dalam penelitian lainnya menerapkan konsep deep learning yang memiliki pengujian yang sangat baik dalam visi komputer. Salah satunya adalah pada kasus klasifikasi objek pada citra. Melalui implementasi dari salah satu metode machine learning yang dapat digunakan untuk klasifikasi citra objek yaitu CNN. Metode CNN terdiri dari dua tahap. Tahap pertama adalah klasifikasi citra menggunakan feedforward. Tahap kedua merupakan tahap pembelajaran dengan metode backpropagation. Sebelum dilakukan klasifikasi, terlebih dahulu dilakukan praproses dengan metode wrapping dan cropping untuk memfokuskan objek yang akan diklasifikasi. Selanjutnya dilakukan training menggunakan metode feedforward dan backpropagation. Terakhir adalah tahap klasifikasi menggunakan metode feedforward dengan bobot dan bias yang diperbarui (Eka Putra 2016).

Menurut (Syahputra, Arnia, and Munadi 2019) adanya pemaparan dari hasil karakterisasi kematangan buah kopi arabika menggunakan dua fitur warna citra, yaitu histogram dan momen warna. Karakterisasi kematangan dibagi menjadi empat kelompok yang meliputi hijau untuk kopi muda, hijau kekuningan untuk kopi setengah masak, merah untuk kopi masak, dan merah tua untuk kopi tua. Tujuan penelitian ini untuk menentukan fitur warna yang dapat mewakili karakter kematangan buah kopi dengan melakukan simulasi komputer untuk mengekstrak dan menghitung nilai statistik dari histogram warna dan nilai momen warna dari empat kelompok buah kopi. Hasil penelitian menggunakan 200 citra kopi menunjukkan bahwa nilai statistik dari histogram warna lebih menggambarkan karakter kematangan buah kopi, dibandingkan dengan momen warna. Nilai kurtosis dari histogram hue memiliki nilai berbeda untuk setiap kategori kematangan buah kopi: kopi muda memiliki nilai kurtosis 17.2-28.3, kopi setengah masak 29.2-31.4, kopi masak 32.7-83.5dan kopi tua lebih dari 84.2.

\section{LANDASAN TEORI}

\subsection{Deep Learning}

Deep learning merupakan salah satu bidang machine learning yang memanfaatkan banyak layer dalam pengolahan informasi nonlinier untuk melakukan ekstraksi fitur, pengenalan pola, dan klasifikasi (Schmidhuber 2015). Adanya pendekatan dalam penyelesaian masalah pada sistem pembelajaran komputer yang menggunakan konsep hierarki. Konsep hierarki membuat komputer mampu mempelajari konsep yang kompleks dengan menggabungkan dari setiap konsep-konsep yang lebih sederhana. Jika digambarkan sebuah graf bagaimana konsep tersebut dibangun di atas konsep yang lain, graf ini akan dalam dengan banyak layer, hal tersebut menjadi alasan disebut sebagai deep learning (pembelajaran mendalam). Seiring dengan banyaknya pengembangan dan riset tentang deep learning, banyak library yang bermunculan dengan fokus mempelajari tentang jaringan syaraf tiruan, salah satu contoh yaitu keras. Keras merupakan library jaringan syaraf tiruan tingkat tinggi yang ditulis dengan bahasa python dan mampu berjalan di atas TensorFlow, CNTK, maupun Theano (Chollet F., 2015). 


\subsection{Konsep Convolutional Neural Network}

Adanya teknik Convolutional Neural Network merupakan salah satu jenis neural network yang biasanya digunakan dalam pengolahan data image. Konvolusi atau biasa yang disebut dengan convolution, berupa matriks yang memiliki fungsi dengan melakukan filter yang terdapat pada Gambar 1. Convolutional layer memiliki beberapa layer yang difungsikan untuk melakukan filter pada setiap prosesnya. Prosesnya disebut dengan proses training (Pinto et al. 2017).

Pada CNN memiliki dua tahapan, yaitu tahap feature learning dan classification. Input gambar pada model CNN menggunakan citra yang berukuran $64 \times 64 \times 3$. Angka tiga yang dimaksud adalah sebuah citra yang memiliki 3 channel yaitu Red, Green, dan Blue (RGB) Citra masukan kemudian akan diproses terlebih dahulu melalui proses konvolusi dan proses pooling pada tahapan feature learning. Jumlah proses konvolusi pada rancangan ini memiliki dua lapisan konvolusi. Setiap konvolusi memiliki jumlah filter dan ukuran kernel yang berbeda. Kemudian dilakukan proses flatten atau proses mengubah feature map hasil pooling layer kedalam bentuk vector. Proses ini biasa disebut dengan tahap fully connected layer

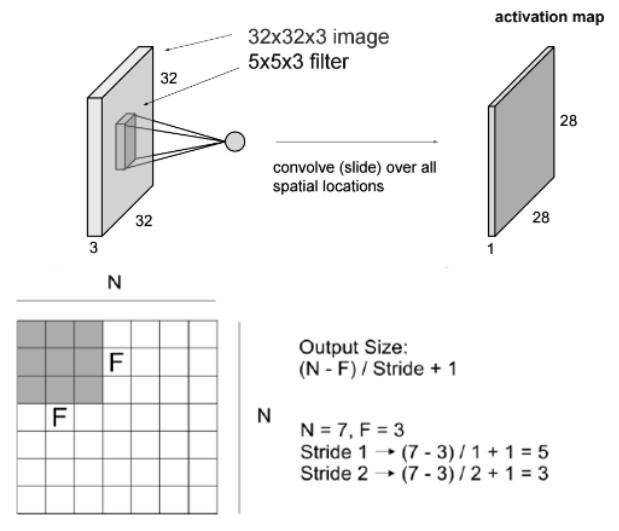

Gambar 1. Convolutional layer

\subsection{Arsitektur CNN}

Neural network terdiri dari berbagai layer dan beberapa neuron pada masingmasing layer. Kedua hal tersebut tidak dapat ditentukan menggunakan aturan yang pasti dan berlaku berbeda-beda pada data yang berbeda.

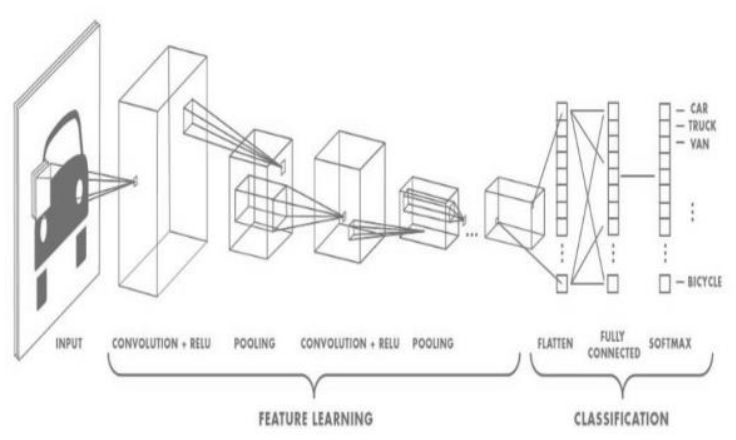

Gambar 2. Arsitektur Convolutional

Neural Network

\section{A. Subsampling}

Subsampling merupakan proses untuk mereduksi ukuran sebuah data citra. Dalam pengolahan citra, subsampling juga bertujuan untuk meningkatkan invariansi posisi dari fitur. Dalam sebagian besar CNN, (Sravya, Krishna, and Suhasini 2019) Metode subsampling yang digunakan adalah max pooling. Max pooling membagi output dari convolution layer menjadi beberapa grid kecil lalu mengambil nilai maksimal dari setiap grid untuk menyusun matriks citra yang telah direduksi.

\section{B. Fully Connected Layer}

Pada bagian feature map yang dihasilkan oleh tahap sebelumnya berbentuk multidimensional array. Sehingga, Sebelum masuk pada tahap fully connected layer, feature map tersebut akan melalui proses flattern atau reshape. Proses flatten menghasilkan sebuah vektor yang akan digunakan sebagai input dari fully connected layer. 
fully connected layer memiliki beberapa hidden layer, action function, output layer dan loss function.

\section{Convolution Layer}

Seluruh data yang menyentuh lapisan konvolusional akan mengalami proses konvolusi. Lapisan akan mengkonversi setiap filter ke seluruh bagian data masukan dan menghasikan sebuah activation map atau feature map 2D. Filter yang terdapat pada convolutional layer memiliki panjang, tinggi (pixels) dan tebal sesuai dengan channel data masukan. Setiap filter akan mengalami pergeseran dan operasi "dot" antara data masukan dan nilai dari filter (Wallelign et al. 2019).

\subsection{Klasifikasi}

Klasifikasi merupakan sebuah proses untuk memperoleh model ataupun fungsi yang melukiskan dan membedakan kelas data maupun konsep yang mempunyai tujuan memprediksikan kelas untuk data yang tidak dikenali kelasnya (J. Han, M. Kamber, 2006). Ada banyak teknik yang dapat dilakukan untuk mengklasifikasikan data, meliputi decision tree, naive bayesian classifier, bayesian belief network dan rule based classifier (Han dan Kamber, 2006). Setiap algoritma klasifikasi tersebut memiliki kelebihan dan kekurangan, tetapi prinsip dari masingmasing algoritma tersebut sama, yaitu melakukan suatu pelatihan sehingga di akhir pelatihan, model dapat memprediksi setiap vektor masukan ke label kelas output dengan tepat (Prasetyo, 2012).

\subsection{Gradient Distance Learning}

Pada jaringan feedforward, pelatihan dilakukan dalam rangka melakukan pengaturan bobot, sehingga pada akhir pelatihan diperoleh bobot-bobot yang terbaik. Selama proses pelatihan, bobotbobot diatur secara iteratif untuk meminimalkan kesalahan fungsi jaringan. Fungsi kesalahan yang sering digunakan adalah minimum square error (MSE), yang mengambil rata-rata kuadrat kesalahan yang terjadi antara output jaringan dan target.

Sebagian besar algoritma pelatihan untuk jaringan feedforward menggunakan gradien dari fungsi kesalahan untuk menentukan perubahan bobot dalam rangka meminimalkan fungsi kesalahan tersebut. Gradien ini ditentukan dengan teknik backpropagation. Prinsip dasar dari algoritma backpropagation sederhana adalah memperbaiki bobot-bobot jaringan dengan arah yang membuat fungsi kinerja menjadi turun dengan cepat. Dengan kata lain, algoritma backpropagation menggerakkan bobot dengan arah gradien negatif.

\subsection{Droupout}

Salah satu teknik untuk mengurangi overfitting adalah menggunakan dropout. Overfitting merupakan kondisi dimana sistem jaringan syaraf tiruan mampu belajar dengan baik dengan data pelatihan, namun tidak bisa menggeneralisasi pada data tes (Rajagede, 2016).

Dengan menggunakan dropout, maka secara acak akan dipilih beberapa neuron lalu dihapus sementara ketika sedang proses pelatihan. Proses ini dilakukan secara berulang, setelah pembaruan nilai bobot dan bias, neuron yang tadinya dihapus dikembalikan lagi, lalu akan dipilih lagi secara acak untuk dihapus dan dilakukan pelatihan lagi, dan seterusnya. Pada saat pelatihan peluang sebuah neuron dihapus adalah $p$. Ketika proses evaluasi atau tes, semua neuron tidak ada yang 
dihapus. Namun, karena saat pelatihan bobot dan bias pada sistem sudah terlatih dengan hilangnya $p$ neuron, maka saat proses evaluasi, bobot yang keluar dari sebuah neuron harus dikali dengan $p$. Ini untuk memastikan output saat proses tes sama dengan saat proses pelatihan, dimana ada kemungkinan $p$ neuron hilang (Srivastava, dkk. 2014).

\section{METODE PENELITIAN}

\subsection{Pengumpulan Data}

Data yang digunakan dalam penelitian ini diambil dari Amankuba Coffee, pengekspor biji kopi di Kabupaten Aceh Tengah, Indonesia. Data diambil dalam lingkungan yang terkontrol dengan menggunakan kamera Canon ixus 860 IS. Secara total, 850 gambar capture yang terdiri dari 430 gambar memenuhi syarat untuk ekspor kopi dan 445 Biji kopi tidak memenuhi syarat untuk ekspor. Dalam pengambilan data awal dipilih beberapa biji kopi yang memungkinkan dengan kriteria memudar, hitam, masam, rusak, peaberry, dan tidak cacat.

\subsection{Preprocessing}

Setelah gambar diperoleh dari proses akuisisi, langkah selanjutnya yaitu melakukan preprocessing untuk menyiapkan gambar untuk proses klasifikasi. Preprocessing bertujuan untuk melakukan segmentasi, memotong dan mengubah ukuran gambar biji kopi. Preprocessing dilakukan dengan memotong area yang hanya berisi biji kopi. Tahapan Ini dilakukan berdasarkan segmentasi biner pada gambar skala abuabu dan mendapatkan koordinat yang pertama dari atas, sisi kanan, sisi kiri, dan bawah gambar. Koordinat akan bertindak sebagai input ke dalam proses pemotongan gambar asli (warna). Setelah mendapatkan gambar berwarna yang telah dipotong, dilakukan pengubahan ukuran gambar untuk membuat ukuran gambar $32 \times 32$ piksel

\subsection{Teknik Convolutional Neural Network}

Setelah melakukan preprocessing, selanjutnya pelatihan CNN untuk satu gambar ditunjukkan pada Gambar 3 . Dalam hal ini gambar, jumlah filter yang digunakan adalah sepuluh. Jumlah filter ditentukan oleh berapa banyak fitur yang digunakan. Nilai berat filter konvolusi, $(\mathrm{K})$, diinisialisasi dengan nilai acak antara $-0,3$ hingga 0,3 .

Nilai berat akan diperbarui selama pelatihan. Ukuran input untuk CNN adalah gambar berwarna dengan ukuran 32x32x3 (tinggi $\mathrm{x}$ lebar $\mathrm{x}$ kedalaman). Gambar input kemudian dialaminya konvolusi. Setelah proses konvolusi, lapisan aktivasi $\mathrm{ReLu}$ diterapkan ke peta fitur. Proses terakhir dalam lapisan konvolusi adalah proses penyatuan, yang dilakukan dengan menggunakan masker penyatuan ukuran $2 \times 2$. Proses ini, dari konvolusi hingga penyatuan, akan diulang sebanyak jumlah lapisan konvolusi yang digunakan. Jumlah lapisan konvolusional, jumlah filter dan ukuran filter adalah parameter yang nilainya dicari dalam penelitian ini untuk mencapai akurasi terbaik

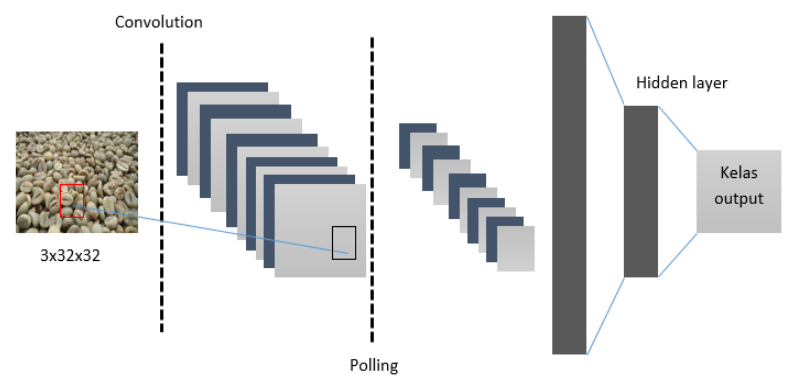

Gambar 3. Proses training pada biji kopi

\section{HASIL DAN PEMBAHASAN}

Penerapan dari proses eksperimen untuk menentukan tingkat pembelajaran yaitu dilakukan dengan lapisan 
konvolusional tunggal dengan mengatur jumlah filter menjadi 15 dengan ukuran $3 \times 3 \times 3$, jumlah neuron dalam lapisan tersembunyi hingga 100.

Model dengan nilai laju pembelajaran lebih besar dari 0,0001 tidak dapat mencapai konvergen. Model dengan nilai laju pembelajaran yang lebih kecil mencapai konvergen dalam waktu yang lebih lama. Ini bisa di proses kembali karena ketika tingkat learning terlalu kecil, maka proses pelatihan tidak hanya lebih lambat, tetapi ada kemungkinan pelatihan tidak mampu mengurangi kesalahan pelatihan. Oleh karena itu, nilai tingkat pembelajaran yang dipilih adalah 0,0001. Dalam skenario awal untuk menentukan jumlah filter adalah dilakukan dengan mengatur laju pembelajaran menjadi 0,0001 dan jumlah neuron di lapisan tersembunyi menjadi 100. Hasil skenario ditunjukkan pada Tabel 1. Hal ini ditunjukkan pada Tabel 1 bahwa akurasi tertinggi yang diperoleh untuk model dua kelas adalah $82.46 \%$ dengan 15 filter dengan ukuran $3 \times 3 \times 3$. Di sisi lain, model empat kelas memperoleh akurasi terbaik $67.75 \%$ dengan 18 filter dengan ukuran $3 \times 3 \times 3$.

Tabel 1 Jumlah dan Ukuran Filter

\begin{tabular}{|l|l|l|}
\hline \multirow{2}{*}{ Filter } & \multicolumn{2}{|c|}{ Jumlah Akurasi (\%) } \\
\cline { 2 - 3 } & Model 2 kelas & Model 4 kelas \\
\hline $\mathbf{1}$ & 64.1 & 52.64 \\
\hline $\mathbf{6}$ & 76.24 & 58.44 \\
\hline $\mathbf{1 0}$ & 76.88 & 64.82 \\
\hline $\mathbf{1 5}$ & 82.46 & 65.04 \\
\hline $\mathbf{1 8}$ & 78.45 & 67.75 \\
\hline $\mathbf{2 5}$ & 78.45 & 66.01 \\
\hline
\end{tabular}

Pengujian berikutnya untuk menentukan jumlah neuron di hidden layer dilakukan dengan mengatur laju pembelajaran ke 0,0001 dan dengan menggunakan jumlah filter dan ukuran filter yang memberikan akurasi terbaik seperti yang ditunjukkan pada Tabel 1.

Jumlah neuron yang mendapatkan akurasi terbaik dalam model dua kelas adalah 100 neuron dengan akurasi $81.50 \%$ seperti yang ditunjukkan pada Tabel 2 . Sedangkan model empat kelas memperoleh akurasi tertinggi $67.05 \%$ dengan menggunakan 150 neuron. Menambah atau mengurangi jumlah neuron dalam lapisan tersembunyi mengurangi akurasi yang diperoleh model.

Tabel 2 Jumlah neuron dalam hidden layer

\begin{tabular}{|c|c|c|}
\hline \multirow{2}{*}{ Filter } & \multicolumn{2}{|c|}{ Jumlah Akurasi (\%) } \\
\cline { 2 - 3 } & Model 2 kelas & Model 4 kelas \\
\hline $\mathbf{5 0}$ & 76.02 & 59.40 \\
\hline $\mathbf{7 5}$ & 76.69 & 64.85 \\
\hline $\mathbf{1 0 0}$ & 81.50 & 66.76 \\
\hline $\mathbf{1 3 0}$ & 78.20 & 66.32 \\
\hline $\mathbf{1 5 0}$ & 77.88 & 67.05 \\
\hline $\mathbf{1 7 5}$ & 78.68 & 66.18 \\
\hline
\end{tabular}

Pada tahap selanjutnya, pengujian untuk menentukan efek lapisan tambahan adalah dilakukan dengan menambahkan lapisan konvolusi ke model terbaik dari percobaan sebelumnya. Penambahan dilakukan di lapisan pertama jaringan. Ukuran filter yang digunakan untuk lapisan konvolusional tambahan adalah $3 \times 5 \times 5$, dengan jumlah filter yang bervariasi selama percobaan. 
Hasil percobaan untuk model empat kelas ditunjukkan pada Tabel 3. Terlihat dalam tabel bahwa akurasi tertinggi yang dicapai adalah $70,73 \%$ dengan menggunakan enam filter di lapisan pertama dan 18 filter di lapisan kedua. Namun, menambahkan lapisan konvolusional untuk model dua kelas tidak menghasilkan peningkatan dalam akurasi. Oleh karena itu akurasi terbaik untuk model dua kelas adalah 81,50 \% dengan lapisan konvolusional tunggal.

Tabel 3 Nilai akurasi pada model 4 kelas

\begin{tabular}{|c|c|c|c|c|}
\hline $\begin{array}{c}\text { Nilai } \\
\text { filter } \\
\text { dengan } \\
\mathbf{1} \text { layer }\end{array}$ & $\begin{array}{c}\text { Ukuran } \\
\text { filter } \\
\text { dengan 1 } \\
\text { layer }\end{array}$ & $\begin{array}{c}\text { Ukuran } \\
\text { filter } \\
\text { dengan 2 } \\
\text { layer }\end{array}$ & $\begin{array}{c}\text { Nilai } \\
\text { pada } \\
\text { neuron } \\
\text { hidden } \\
\text { layer }\end{array}$ & $\begin{array}{c}\text { Nilai } \\
\text { akurasi } \\
\text { untuk 4 } \\
\text { kelas }\end{array}$ \\
\hline $\mathbf{1 6}$ & $3 \times 5 \times 5$ & 18, & 150 & 70.73 \\
\hline $\mathbf{1 2}$ & $3 \times 5 \times 5$ & $\begin{array}{c}18, \\
6 \times 3 \times 3\end{array}$ & 150 & 70.10 \\
\hline $\mathbf{1 8}$ & $3 \times 5 \times 5$ & $\begin{array}{c}12 \times 3 \times 3 \\
18 \times 3 \times 3\end{array}$ & 150 & 68.26 \\
\hline & & & & \\
\hline & & & & \\
\hline
\end{tabular}

\section{SIMPULAN DAN SARAN}

Dari penelitian yang telah di lakukan, maka dapat diambil kesimpulan dan saran sebagai berikut.

Kesimpulan

Pada penelitian ini berdasarkan hasil percobaan dari penelitian ini, bisa jadi menyimpulkan bahwa convolutional neural network berkinerja lebih baik dibandingkan dengan teknik tradisional untuk mengklasifikasikan kecacatan biji kopi arabika. Selain itu, lapisan konvolusional tunggal yang digunakan dalam CNN mampu memberikan $82,46 \%$ untuk klasifikasi model dua kelas dan 67,05\% untuk klasifikasi model empat kelas. Penambahan lapisan konvolusi mampu meningkatkan akurasi model empat kelas menjadi 70,73\%.

Saran

a. Pengembangan deep learning untuk model convolutional neural network dapat ditingkankan melalui arsitekur VGG16 maupun Inception v3.

b. Untuk akurasi pada nilai cacat dapat diterapkan pada perbandingan biji kopi yang lain seperti halnya biji kopi robusta.

\section{DAFTAR PUSTAKA}

Effendi, Masud, Fitriyah Fitriyah, and Usman Effendi. 2017. "Identifikasi Jenis Dan Mutu Teh Menggunakan Pengolahan Citra Digital Dengan Metode Jaringan Syaraf Tiruan." Jurnal Teknotan 11(2): 67.

Eka Putra, Wayan Suartika. 2016. "Klasifikasi Citra Menggunakan Convolutional Neural Network (CNN) Pada Caltech 101." Jurnal Teknik ITS 5(1).

Lu, Yiyao et al. 2013. "Annotating Search Results from Web Databases." IEEE Transactions on Knowledge and Data Engineering 25(3): 514-27.

Pinto, Carlito, Junya Furukawa, Hidekazu Fukai, and Satoshi Tamura. 2017. "Classification of Green Coffee Bean Images Basec on Defect Types Using Convolutional Neural Network (CNN)." Proceedings - 2017 International Conference on Advanced Informatics: Concepts, Theory and Applications, ICAICTA 2017.

Schmidhuber, Jürgen. 2015. "Deep Learning in Neural Networks: An Overview." Neural Networks 61: 85117. http://dx.doi.org/10.1016/j.neunet.201 
4.09.003.

Sravya, Saripalli Sri, Kalva Sri Rama Krishna, and Pallikonda Sarah Suhasini. 2019. "Image Classification Using Supervised Convolutional Neural Network." International Journal of Recent Technology and Engineering 8(2): 4505-7.

Syahputra, Hendri, Fitri Arnia, and Khairul Munadi. 2019. "Karakterisasi Kematangan Buah Kopi Berdasarkan Warna Kulit Kopi Menggunakan Histogram Dan Momen Warna." Jurnal Nasional Teknik Elektro 8(1): 42.
Wallelign, Serawork, Mihai Polceanu, Towfik Jemal, and Cédric Buche. 2019. "Coffee Grading with Convolutional Neural Networks Using Small Datasets with High Variance." Journal of WSCG 27(2): 113-20.

Zhang, Jing et al. 2017. "Image Retrieval Using The Extended Salient Region." Information Sciences 399: 1339-51. 